ISSN: 2162-3104 Print/ ISSN: 2166-3750 Online

Volume 8, Issue 3 (2018), pp. 1328-1336

(C) Journal of International Students

http://jistudents.org/

doi: $10.5281 /$ zenodo. 1254588

\title{
Building Bridges Across the International Divide: Fostering Meaningful Cross-Cultural Interactions Between Domestic and International Students
}

\author{
CindyAnn Rose-Redwood \\ University of Victoria, Canada \\ Reuben Rose-Redwood \\ University of Victoria, Canada
}

\begin{abstract}
In this article, we consider the ways in which both formal and informal social practices at colleges and universities can lead domestic and international students to engage in meaningful cross-cultural interactions. Employing a narrative-based approach, we reflect upon our own personal experiences as domestic students who developed close friendships with international students at two higher education institutions in the United States at the turn of the twenty-first century. In one case, an international friendship grew from a formal, university-sponsored conversation partner program organized by the university's international office, and, in the other case, a close friendship with an international student emerged through informal social interactions on a college campus. Taken together, these cases suggest that higher education settings have the potential to be spaces of meaningful cross-cultural interaction. However, this requires an active commitment on the part of both domestic and international students to engage in social interactions across the international divide.
\end{abstract}

Keywords: conversation partner programs, cross-cultural interactions, narrative, international friendships, international students

College and university campuses have the potential to be ideal settings in which to foster cross-cultural interactions and meaningful international friendships. Studies suggest that international students often build cross- 
cultural friendships with other students from around the world when studying abroad, yet social interactions between domestic and international students are generally more limited, particularly in the United States (Trice 2004; Gareis, Merkin, and Goldman 2011; Gareis 2012; Rose-Redwood and Rose-Redwood 2013). This lack of social engagement has important implications not only for the student experience itself; it also shapes the social networks and professional opportunities that students encounter once they have completed their studies. If domestic students only interact with their domestic peers, this will most likely have the effect of limiting their cultural literacy as well as diminishing their ability to socially and professionally interact with people from diverse cultural backgrounds in different geographical contexts. As Lee suggests, there is a "need to concentrate on how to enhance the quality of intercultural friendships and how to make such relationships work" (2006, p. 6). How, then, might meaningful cross-cultural interactions and international friendships be fostered on college and university campuses? What formal and informal practices can effectively break down the social barriers between domestic and international students? Put simply, how might we actively seek to build bridges across the international divide in higher education settings?

This article seeks to address these issues by reflecting on our own personal experiences as domestic students interacting with international students at two higher education institutions on the East Coast of the United States around the turn of the twenty-first century. We employ a narrativebased approach to frame our discussion, which enables us consider the intricacies of how international friendships develop within higher education contexts. In one case, an international friendship with a Malaysian student grew from a formal, university-sponsored conversation partner program organized by the university's international office, and, in the other case, a close friendship with an international student from Tanzania emerged through informal social interactions on a college campus. Although the mode of initial contact differed in each case, both resulted in lasting friendships that not only expanded our social networks and cultural capital but also broadened what we might call our "geographical empathy" based upon an ethic of care for those living in distant places around the world.

In the remainder of this article, each of the present authors provides a narrative account of our experiences developing an international friendship in a higher education setting. Our aim is not to claim that these experiences are representative of international friendships in general but rather to highlight how both formal and informal opportunities exist on college and university campuses that can facilitate the development of meaningful, longlasting friendships between domestic and international students. For far too 
many domestic students, the lack of cross-cultural engagement with international students results in a series of missed opportunities that could have enhanced their educational experience and enriched their understanding of the world. We hope that our stories will inspire more domestic students to cultivate their own international friendships and assist higher education professionals by illustrating two cases in which domestic and international students sought to break down the social and cultural divides on college and university campuses.

\section{PERSONAL NARRATIVE \#1: A JOURNEY FROM CONVERSATION PARTNER TO INTERNATIONAL FRIENDSHIP}

As a young Caribbean women of East Indian descent, I (CindyAnn) moved from Trinidad to New York City in 1992, and I attended both high school and college in New York. Spending my formative years in a city of immigrants provided me with a deep understanding of the value of learning how to socially interact with people from a diverse array of cultures and world regions while also navigating between the "Western" idioms of American popular culture and my own creolized cultural upbringing. After completing my undergraduate degree in New York, I moved to Pennsylvania to pursue my graduate studies. While in graduate school, I interacted with a wide variety of students from different parts of the U.S. and abroad, and it was also during this time that I became a naturalized U.S. citizen. When I started my graduate studies, I was the only domestic, visible minority student in my incoming departmental cohort, and I interacted with both domestic and international students alike, playing the role of cultural chameleon so common among Caribbean islanders. On the one hand, I could fit in with domestic students because I had spent the past decade living in the U.S. and could speak excellent English, which is, after all, my mother tongue having been born in a former British colony in the Caribbean. Yet, on the other hand, my international origins helped me to form connections with international students from India, the UK, Australia, and Colombia.

Given my own hybrid social identity, I found myself placed at the intersections of both domestic and international students' social networks, which is part of what led me to volunteer in the university's conversation partner program, organized by the international student office on campus. When I saw an advertisement for the program, I thought it would be a great opportunity to help an international student practice their English language skills, since I knew that language barriers are often one of the greatest challenges impeding cross-cultural interactions between domestic and international students. I had seen this firsthand while living in New York, 
where many of my friends in high school and college were newcomers to the United States, so I understood how difficult learning English could be for non-native English language speakers. In other words, I had developed a strong sense of empathy for international students even before arriving at the university, which predisposed me to seek out formal opportunities such as volunteering in the conversation partner program. When I contacted the international student office to inquire about this program, they matched my profile with a young woman from Malaysia who was taking English language classes while her husband pursued a graduate degree. After both of us agreed to become conversation partners, the international student office provided us with each other's contact email and guidelines about our responsibilities as conversation partners.

I first met Zara (pseudonym) for coffee on campus, and we decided that it would be best to meet periodically throughout the academic year and to select "focused topics" for discussion during our meetings. As it turned out, Zara was already a good English speaker when I first met her, but she just wanted more practice speaking the language and was also interested in learning more about American culture and the colloquial "lingo" of everyday speech. She was particularly fascinated by my ability to "fit in" with domestic students despite the fact that I had been an immigrant to the U.S. and had only recently become a citizen.

Our conversations explored a wide range of different topics related to current events. Sometimes we would discuss local events occurring on the university campus, and other times Zara would bring a newspaper article about a national or global event. One of our very first conversations was about U.S. politics and then President George W. Bush's recent speech about the War on Terror and the "clash of civilizations." She asked me to explain what this "clash" was about, which led us to reflect on how our own cross-cultural interactions challenged the belief that cultural difference must necessarily lead to antagonism.

Over the course of a year, we met regularly and discussed everything from the myths and fairytales in different cultures to our own dreams, desires, and passions. Around the time of Halloween, Zara was curious to learn more about the American obsession with myths of vampires, ghosts, and werewolves. The more we shared stories about cultural myths, we began to realize how similar they were across cultures, and we found it amusing that the point of many cultural myths in different cultures was to scare little kids into listening to their parents so they wouldn't get into trouble.

At the time, Zara wasn't sure whether she would stay in the U.S. or go back to Malaysia after her husband completed his studies. We stayed 
good friends for the remaining three years that I spent completing my doctoral research, continuing to meet regularly for coffee once a week, but eventually we began to socialize in other ways as well. For instance, she invited my partner and me to her house for a homemade Malaysian dinner. This was one of the most memorable experiences of our friendship, and I came to appreciate the significance of sharing food as an important part of fostering hospitality, mutual understanding, and friendship across cultural differences.

Over a decade has passed since Zara and I last saw each other, and it turned out that both of us would end up leaving the United States-her to Singapore and myself to Canada. We both have children of our own now and see each other's lives through Facebook. Although we live far apart, I still value our friendship which had its beginnings in a university-sponsored conversation partner program.

\section{PERSONAL NARRATIVE \#2: INTERNATIONAL FRIENDSHIP BEYOND THE INSTITUTIONAL FRAME}

As a U.S.-born man of Eastern European Jewish descent with family ties to New York City, I (Reuben) grew up in the suburbs of Washington, DC, during the 1980s and 1990s. Many of my high school peers were the children of international diplomats, World Bank officials, and other professionals, which exposed me to a diversity of cultures and international perspectives prior to pursuing higher education. In 1996, I enrolled in a small, liberal arts college in rural Virginia and then transferred to a larger research university about an hour away in the middle of my second year. However, the friendships that I made during my freshman year of college remained strong even though I transferred to a different university, and one of those friendships was with an international student from Tanzania.

I first met Jeremiah (pseudonym) in the college dining hall when one of my anthropology professors introduced us, and we then began to meet regularly for meals over the course of the semester. I had never been to Sub-Saharan Africa before, and I was intrigued to learn more about Jeremiah's life experiences and home country. Jeremiah was also curious about American culture and how it compared to his own cultural values. I recall us discussing everything from American misconceptions of Africa and how such stereotypes compare with the everyday lives of Africans, on the one hand, to the U.S. Constitution and race relations in the United States, on the other hand. We were both intimately aware of the racial divide on campus and in the surrounding community, since the town in which the 
college was located had a long history of segregation along racial lines as well as anti-black racism and discrimination.

Although we came from different cultural backgrounds, the more we got to know each other, the more it became evident that we shared many common interests. For instance, we were both passionate about issues of social and environmental justice. Jeremiah was particularly inspired by role models such as Nelson Mandela, Malcolm X, and Martin Luther King Jr. Similarly, I had grown up hearing my parents tell stories about the civil rights movement and how they had been involved with the anti-war movement as well as the grape boycotts that César Chávez led with the United Farm Workers in California. However, our friendship went beyond questions of politics and intellectual concerns, since we also went to see movies together, drove around town on the weekends, went shopping, and engaged in various other everyday activities of friendship.

After transferring to a different university, I began volunteering as an organizer of a guest speaker series in my academic department, and one semester I invited Jeremiah to give a talk about his experiences with environmental conservation in Tanzania. I also regularly visited Jeremiah and my other friends back at the college that I had left on the weekends, and we maintained our friendship even after we both received our undergraduate degrees and went to graduate school. Then, after completing my master's degree at a research university in Pennsylvania, I finally took Jeremiah up on an invitation to visit him in Tanzania for about a month during the summer of 2002, which was one of the most incredible experiences I've ever had travelling abroad. His family welcomed me into their home with warm hospitality, and so too did the entire village, especially the school kids.

During my visit to Tanzania, our roles were reversed with Jeremiah hosting me in his home country. Now it was I who played the role of the "outsider," since I was seen as a visible minority, albeit a very privileged one, in Jeremiah's home town. I lost track of the number of times kids would point to me and call out, "mzungu" (white person), as I passed them on the road. While in Tanzania, I had many opportunities for cross-cultural interaction, including sharing home-cooked meals with Jeremiah's family and playing a board game called bao with Jeremiah and other villagers. One of the most memorable experiences occurred sitting outside by a fire on a warm, moonlit summer night. When we approached the fire, a village elder was telling an origin story about his people and the land, and when he finished the group asked me to tell a mythic story about my "culture." At first, I was at a loss, since I wasn't religious and could not immediately think of a secular origin myth from the West. After a moment's reflection, I 
decided to tell them the myth of Plato's cave with my own variation on the ending - instead of seeing the light of Truth when leaving the cave at the end of the story, the truth-seeker wanders into another cave and mistakes the shadows for reality yet again. Although I wasn't a master-storyteller, the group seemed to enjoy the tale and we all had a good laugh at my attempt at cross-cultural, mythological storytelling.

After my trip to Tanzania, Jeremiah and I kept in touch as we continued to pursue our doctoral studies. He came to visit me twice and I went to see him as well during this time. When I got my first tenure-track faculty job in Texas, I invited him to give a public lecture at the university as well. Then, when I moved to British Columbia, Canada, a year later, he came to visit me there on the way to a conference he was attending a few hours away in 2010. Now that he has completed his doctoral studies and moved back to Tanzania, we keep in touch by phone and via social media, and he remains one of my closest friends despite the physical distance between us.

\section{CONCLUDING REFLECTIONS}

In this reflective article, we have drawn upon our own educational experiences to illustrate that college and university campuses have the potential to serve as spaces of meaningful cross-cultural interaction between domestic and international students. However, this potential all-too-often goes unfulfilled for a variety of different reasons (Rose-Redwood 2010). As domestic students, we both had the good fortune of developing international friendships as part of our university experience. In CindyAnn's case, a formal university-sponsored conversation partner program initiated an international friendship, whereas in Reuben's case a friendship emerged from a chance encounter in the college cafeteria. Although the two cases discussed above are unique, there are a number of lessons that can be drawn from these experiences that may have broader relevance for efforts to foster cross-cultural interactions and international friendships in higher education settings.

The first main lesson from this study is that cross-cultural interactions and international friendships can arise from both formal and informal encounters on college and university campuses. Universitysponsored events and initiatives, such as conversation partner programs, can play an important role in fostering social interactions between domestic and international students. In some cases, these formal connections may even lead to the development of meaningful friendships that extend beyond the confines of the initial program itself. In other instances, international 
friendships may develop from chance encounters on campuses that are not pre-determined by institutional programs. Yet, regardless of the means of first contact, such connections are dependent upon an openness and willingness among both parties to engage in cross-cultural dialogue.

The second lesson worth considering is that domestic students who have had cross-cultural experiences before going to college or university may be more likely to develop friendships with international students while pursuing higher education. This was certainly true in the two cases discussed above, although further research is needed to better understand whether this claim is generalizable. Based on our own experiences, however, it is clear that having been exposed to diverse cultures and perspectives prior to becoming university students led both of us to be more proactive in developing international friendships on college and university campuses. Yet, even in such cases, it would have been easier to socially interact with other domestic students within our established social networks, since it requires an active effort to reach out across the international divide of campus life.

The third main lesson to be learned from our narrative accounts is that international friendships which develop on college and university campuses may extend beyond the spatial and temporal boundaries of student life on campuses themselves. Such friendships may lead domestic students or alumni to travel abroad to visit international students in their home countries, which may not necessarily be part of a formal study abroad program. These international connections could possibly even lead domestic students to relocate abroad after they have completed their studies. It is understandable that higher education professionals tend to be more concerned with the international student experience on higher education campuses themselves, yet from a student's perspective the development of international friendships forges global connections and the university campus is merely one node within a global geography of social and professional networks that extend across space and time (Rose-Redwood \& Rose-Redwood 2013).

Lastly, at a time when xenophobic sentiments are on the rise, higher education institutions have an important role to play in broadening the horizons of our ethic of care beyond the narrow confines of nationalistic parochialisms. Our own experiences have led us to develop a greater sense of empathy with those living in other countries, particularly in places where we have friends who we initially met at university. Yet developing such an ethic of care cannot be achieved through formal institutional programs alone. Both domestic and international students themselves need to work toward building more bridges rather than walls and commit to meeting each 
other halfway across the international divide on college and university campuses.

\section{REFERENCES}

Gareis, E. (2012). Intercultural friendships: Effects of home and host region. Journal of International and Intercultural Communication 5(4): 309-328.

Gareis, E., Merkin, R., \& Goldman, J. (2011). Intercultural friendship: Linking communication variables and friendship success. Journal of Intercultural Communication Research 40(2): 153-171.

Lee, P-W. (2006). Bridging cultures: Understanding the construction of relational identity in intercultural friendship." Journal of Intercultural Communication Research 35(1): 3-22.

Rose-Redwood, C. (2010). The challenge of fostering cross-cultural interactions: A case study of international graduate students' perceptions of diversity initiatives. College Student Journal 44(2): 389-399.

Rose-Redwood, C. and Rose-Redwood, R. (2013). Self-segregation or global mixing? Social interactions and the international student experience. Journal of College Student Development 54(4): 413-429.

Trice, A. (2004). Mixing it up: International graduate students' social interactions with American students. Journal of College Student Development 45(6), 671-687.

CINDYANN ROSE-REDWOOD, $\mathrm{PhD}$, is an Assistant Teaching Professor in the Department of Geography at the University of Victoria. Her research examines the social experiences of international students in higher education settings, the social geographies of immigrant communities in North American cities, and the Caribbean diaspora. She is currently co-editing a book entitled, International Encounters: Higher Education and the International Student Experience (with Reuben Rose-Redwood). Email: cindyann@uvic.ca

REUBEN ROSE-REDWOOD, $\mathrm{PhD}$, is an Associate Professor in the Department of Geography at the University of Victoria. His research examines the cultural politics of place, critical social theory, and the spatialities of power. He is the editor of Performativity, Politics, and the Production of Social Space (2014, with Michael Glass), The Political Life of Urban Streetscapes: Naming, Politics, and Place (2018, with Derek Alderman and Maoz Azaryahu), and Gridded Worlds: An Urban Anthology (2018, with Liora Bigon). He is currently co-editing a book entitled, International Encounters: Higher Education and the International Student Experience (with CindyAnn RoseRedwood). Email: redwood@uvic.ca 